\title{
ANALISIS MINAT BELAJAR MAHASISWA FKIP UNIVERSITAS PAPUA PADA PEMBELAJARAN ONLINE
}

\author{
Cendy Chaterine Manopo ${ }^{1}$, Sri Wahyu Widyaningsih ${ }^{2}$, Sri Rosepda Br. Sebayang ${ }^{3}$ \\ chaterine98m@gmail.com \\ ${ }^{1,2,3}$ Program Studi Pendidikan Fisika, Universitas Papua, Papua, Indonesia
}

Received: 13 November 2020

Revised: 30 November 2020

Accepted: 8 Desember 2020

\begin{abstract}
This study aims to analyze the learning interests of FKIP University Papua students in online learning. The research method used is a survey method using a questionnaire. The sampling technique used was purposive sampling, with a sample of 100 students from all study programs in the FKIP, University of Papua. The instrument used in this study was a student learning interest questionnaire consisting of 15 statements. The results of the analysis show that the level of interest in learning from Papua University FKIP students falls into three categories. On the indicator of pleasure, the results of interest in learning are very high as much as $23 \%$, categories of high interest in learning as much as $56 \%$, and categories of interest in learning as much as $19 \%$, and low category as much as $2 \%$. In the indicator of interest, it was found that the results of interest in learning were very high as much as $22 \%$, categories of high interest in learning as much as $64 \%$, categories of interest in learning as much as $13 \%$, and low category as much as $1 \%$. In the indicator of attention, the results of interest in learning were very high as much as $8 \%$, the category of high interest in learning was $61 \%$, the category of interest in learning was 29\%, and the category for the low category was $2 \%$. The most visible learning interest is interest in learning with an indicator of interest, namely a sense of interest in solving the questions given during online learning
\end{abstract}

\begin{abstract}
Abstrak: Penelitian ini bertujuan untuk menganalisis minat belajar mahasiswa FKIP Universitas Papua pada pembelajaran online. Metode penelitian yang digunakan adalah metode survey dengan menggunakan angket. Teknik pengambilan sampel yang digunakan adalah purposive sampling, dengan sampel 100 mahasiswa dari seluruh program studi yang ada di FKIP Universitas Papua. Instrumen yang digunakan dalam penelitian ini adalah angket minat belajar mahasiswa yang terdiri dari 15 pernyataan. Hasil analisis menunjukkan bahwa tingkat minat belajar mahasiswa FKIP Universitas Papua masuk dalam tiga kategori. Pada indikator rasa senang didapatkan hasil minat belajar belajar sangat tinggi sebanyak 23\%, kategori minat belajar tinggi sebanyak 56\%, dan kategori minat belajar sedang sebanyak $19 \%$, dan kategori rendah sebanyak $2 \%$. Pada indikator rasa tertarik didapatkan hasil minat belajar belajar sangat tinggi sebanyak $22 \%$, kategori minat belajar tinggi sebanyak $64 \%$, kategori minat belajar sedang sebanyak $13 \%$, dan kategori rendah sebanyak $1 \%$. Pada indikator rasa perhatian didapatkan hasil minat belajar belajar sangat tinggi sebanyak $8 \%$, kategori minat belajar tinggi sebanyak $61 \%$, kategori minat belajar sedang sebanyak $29 \%$, dan kategori rendah sebanyak $2 \%$. Minat belajar yang paling terlihat adalah minat belajar dengan indikator rasa tertarik yaitu adanya rasa tertarik untuk menyelesaikan soal-soal yang diberikan selama pembelajaran online.
\end{abstract}

Kata kunci: Minat Belajar, Pembelajaran Online

\section{PENDAHULUAN}

Pendidikan merupakan hal yang penting dalam kehidupan seseorang, karena melalui pendidikan seseorang memperoleh pengetahuan, pemahaman, cara bertingkah laku dan 
peradaban manusia pada masa yang akan datang. Kemajuan suatu bangsa sangat ditentukan oleh kualitas sumber daya manusia yang bergantung pada kualitas pendidikan. Pendidikan yang baik pada dasarnya pendidikan yang menghasilkan seseorang yang tinggi kemampuannya untuk belajar (learning to learn), untuk memecahkan masalah (learning to solveproblem), dan untuk hidup (learning to be) (Lovisia, E, 2019). Sesuai dengan visi pendidikan nasional yaitu terwujudnya sistem pendidikan sebagai pranata sosial yang kuat berwibawa dan berkualitas sehingga mampu menjawab tantangan jaman yang selalu berubah, maka mutu pendidikan harus ditingkatkan dan diselenggarakan secara efektif, artinya Kegiatan Belajar Mengajar (KBM) dapat berjalan secara lancar, terarah dan sesuai dengan tujuan pembelajaran. Tujuan pembelajaran tersebut dapat tercapai bila guru dapat menjalankan fungsinya dengan baik, guru sebagai fasilitator sehingga guru dapat menggunakan kesempatan yang ada sebaik-baiknya untuk proses pembelajaran yang efektif. Kriteria kegiatan belajar mengajar yang efektif: (1) kegiatan belajar mengajar mampu mengembangkan konsep generalisasi serta bahan abstrak menjadi hal yang mudah dimengerti (2) kegiatan belajar mengajar dapat melayani dan diterima dengan kemampuan belajar yang berbeda-beda, dan (3) kegiatan belajar mengajar melibatkan peserta didik aktif pada proses pembelajaran sehingga kegiatan belajar mengajar mampu mencapai tujuan sesuai program yang telah diterapkan. Peserta didik yang aktif dan kreatif didukung fasilitas serta guru yang menguasai materi dan strategi penyampaian secara efektif akan semakin menambah kualitas KBM. Dalam pendidikan di sekolah, berhasil tidaknya pendidikan tidak hanya ditentukan oleh proses belajar mengajar yang telah dilakukan tetapi ditentukan juga oleh guru sebagai media dan fasilitator pembelajaran (Ariani, T., \& Yolanda, Y, 2019).

Pendidikan pada era digital lebih banyak dilakukan dengan pemanfaatan media internet. Internet adalah alat penghubung antara satu orang dan orang lainnya, sehingga tercipta sebuah komunikasi secara virtual. Internet juga dapat digunakan untuk membantu dalam bidang pendidikan guna menjadi salah satu sumber belajar. Internet yang digunakan dalam bidang pendidikan biasa dikenal dengan nama e-learning (Megawati, 2014). E-learning merupakan istilah populer dalam pembelajaran online berbasis internet yang pada hakikatnya merupakan pembelajaran melalui pemanfaatan teknologi (Prasojo \& Riyanto, 2011). Pembelajaran online sendiri mulai ramai digunakan pada awal tahun 2020, dikarenakan oleh keadaan yang terjadi di Indonesia.

Pendidikan pada awal tahun 2020 di Indonesia mengalami sebuah perubahan, terkhusus karena adanya kebijakan untuk melakukan segala sesuatu dari rumah. Kebijakan tersebut 
dibuat dikarenakan penyebaran virus corona atau yang dikenal dengan covid-19, serta perkembangan virus yang dengan cepat menular (Khasanah et al., 2020).. Meskipun begitu aktivitas belajar mengajar harus tetap dilaksanakan, tetapi dengan mematuhi kebijakan yang sudah dikeluarkan oleh pemerintah. Solusi yang digunakan oleh hampir seluruh lembaga pendidikan dalam melaksanakan pembelajaran adalah melakukan pembelajaran secara online.

Pembelajaran online merupakan pembelajaran yang dilakukan secara online. Pemanfaatan pembelajaran online sendiri dilakukan karena memiliki keuntungan antara lain: (a) biayanya yang murah, (b) dapat diakses kapan saja dan dimana saja, (c) memanfaatkan teknologi-teknologi terbaru (Sukmadinata, 2009). Universitas Papua merupakan salah satu perguruan tinggi yang ada di Provinsi Papua Barat yang menerapkan pembelajaran online yang digunakan sebagai pengganti pertemuan di kampus yang tidak bisa dilakukan pada saat ini. Penggunaan pembelajaran online dalam bidang pendidikan ini diharapkan dapat membuat minat belajar mahasiswa tercipta dalam proses pembelajaran.

Menurut KBBI, minat adalah kecenderungan dan kegairahan yang tinggi atau keinginan yang besar terhadap sesuatu. Suharsimi mengatakan bahwa minat adalah penerimaan akan suatu hubungan antara diri sendiri dengan sesuatu diluar diri (Arikunto S. , 2003). Sadirman mengatakan bahwa minat diartikan sebagai suatu kondisi yang terjadi apabila seseorang melihat ciri-ciri atau arti sementara situasi yang dihubungkan dengan keinginan-keinginan atau kebutuhannya sendiri (Sadirman, 2011). Minat belajar sendiri sangat dibutuhkan dalam menjalankan pembelajaran online. Minat belajar yang diperlukan terbagi dalam 3 indikator yaitu: (a) adanya perhatian, (b) adanya ketertarikan, (c) rasa senang. Minat belajar sangat besar pengaruhnya terhadap hasil belajar, karena apabila bahan pelajaran yang dipelajari tidak sesuai dengan minat, siswa tidak siswa yang kurang berminat dalam belajar. Dalam belajar diperlukan suatu pemusatan perhatian agarapa yang dipelajari dapat dipahami. Dalam meningkatkan minat belajar siswa, proses pembelajaran dapat dilakukand engan penciptaan yang lain, pendidikan sebagai penghubung dua sisi, di satu sisi individu yang sedang tumbuh dan disisi lain nilai sosial, intelektual, dan moral yang akhirnya menjadi tanggung jawabpendidik untuk mendorong individu tersebut. Setiap orangtua yang menyekolahkan anaknya menginginkan anaknya meraih nilai yang baik. Namun untuk mencapai hal itu bukanlah suatu hal yang mudah (Charli, L., Ariani, T., \& Asmara, L, 2019). Pembelajaran online merupakan salah satu cara pelaksanaan pembelajaran yang sangat diperlukan pada saat ini, mengapa? Karena pembelajaran online dapat memudahkan pendidik maupun peserta didik dalam melaksanakan pembelajaran kapan saja dan dimana saja ditengah pandemi yang 
kita hadapi. Kesimpulannya adalah dalam penggunaan pembelajaran online diperlukan minat belajar dari peserta yang mengikuti pembelajaran. Oleh karena itu, perlu adanya analisis minat belajar yang dilakukan guna mengetahui minat belajar dari peserta yang mengikuti pembelajaran online.

Penelitian serupa tentang analisis minat belajar terhadap pembelajaran online ditemukan pada jurnal-jurnal penelitian yang tersedia secara online. Salah satu penelitian tentang minat belajar sudah dilakukan oleh Hemayanti (2020) dengan judul "Analisis Minat Belajar Siswa Kelas XI MIA Pada Mata Pelajaran Kimia”. Hasil penelitian yang didapatkan menunjukkan bahwa minat belajar kimia XI MIA adalah 38\% siswa yang tergolong tinggi, 51\% siswa yang tergolong sedang, dan $11 \%$ siswa tergolong rendah. Referensi ini membuat peneliti menjadi tertarik untuk melakukan penelitian guna menganalisis minat belajar pada mahasiswa terhadap pembelajaran online.

Berdasarkan latar belakang yang sudah dipaparkan sebelumnya peneliti akhirnya memutuskan untuk melakukan penelitian yang diberi judul "Analisis Minat Belajar Mahasiswa FKIP Universitas Papua pada Pembelajaran Online". Tujuan dari penelitian ini adalah menganalisis minat belajar mahasiswa FKIP UNIPA terhadap pembelajaran online.

\section{LANDASAN TEORI}

Minat diartikan sebagai salah satu aspek psikis manusia yang dapat mendorong untuk mencapai tujuan. Jika seseorang memiliki minat terhadap sebuah objek akan cenderung untuk memberikan perhatian maupun rasa senang terhadap objek tersebut. Namun, apabila objek tersebut tidak menimbulkan adanya rasa senang maka rasa minat juga akan hilang (Norva, 2015). Fungsi minat dalam belajar berperan dalam motivating force yaitu sebagai kekuatan pendorong untuk belajar. Secara umum, minat dapat berperan penting bagi pengalaman seseorang, salah satu fungsi dari minat juga adalah memberikan efek positif bagi kebiasaan seseorang. Peserta yang berminat terhadap pembelajaran akan terdorong terus untuk tekun belajar, berbeda dengan yang hanya mengikuti pembelajaran akan sulit untuk tekun karena tidak memiliki faktor pendorongnya (Oktarika, 2015). Ahli pendidikan bernama Slameto berpendapat bahwa cara paling efektif untuk mebangkitkan minat pada suatu objek adalah dengan menggunakan minat-minat yang sudah ada maupun membentuk minat baru pada diri peserta didik. Indikator-indikator minat belajar terdiri dari: (a) adanya perhatian, (b) adanya ketertarikan, (c) rasa senang. Indikator perhatian dijabarkan menjadi tiga, antara lain 
perhatian terhadap bahan pelajaran, memahami materi, dan menyelesaikan soal-soal (Slameto, 2010).

Pembelajaran online adalah sarana di bidang pendidikan yang menggabungkan motivasi, komunikasi, dan teknologi. Pembelajaran online merupakan sarana pembantu dalam bidang pendidikan yang membuat proses pembelajaran semakin mudah. Pemicu dari pertumbuhan pembelajaran online adalah konsep longlife learning atau pembelajaran sepanjang hayat (Mason \& Rennie, 2009). Pembelajaran online merupakan bentuk pembelajaran jarak jauh yang memanfaatkan teknologi informasi dan telekomunikasi. Tujuan penggunaan pembelajaran online untuk membantu peserta yang mengikuti pembelajaran agar pembelajaran lebih mudah untuk diikuti. Pembelajaran online memiliki manfaat yang sangat beragam. Menurut Aristo (2003) manfaat pembelajaran online antara lain: (a) meningkatkan kualitas belajar, (b) efesiensi terhadap waktu dan tenaga, (c) proses pembelajaran menjadi lebih menarik, (d) memungkinkan proses pembelajaran dapat dilakukan dimana saja dan kapan saja, dan (e) merubah peran pendidik ke arah yang lebih positif dan produktif.

\section{METODE PENELITIAN}

Metode penelitian yang digunakan pada penelitian ini adalah metode survey dengan menggunakan angket atau kuisioner sebagai bahan instrumennya. Teknik pengumpulan data yang digunakan dalam penelitian ini yaitu angket minat belajar mahasiswa. Mahasiswa yang menjadi sampel penelitian dipilih menggunakan teknik Purposive sampling yang merupakan teknik sampling yang cukup sering digunakan oleh para peneliti (Sugiyono, 2013). Sampel diambil menggunakan kriteria yang telah ditetapkan oleh peneliti, yaitu mahasiswa yang mengikuti pembelajaran yang dilakukan secara online. Angket minat belajar yang digunakan terdiri dari 15 pernyataan yang terdiri dari pernyataan positif dan pernyataan negatif. Pernyataan ini sebelum disebarkan sudah terlebih dahulu divalidkan pada validator ahli dan dianalisis kevalidannya. Angket minat belajar ini dibuat dalam format google form dan disebarkan link angketnya lewat aplikasi whatsapp. Angket ini diisi oleh mahasiswa FKIP Universitas Papua yang berjumlah 100 orang dan mengikuti pembelajaran online. Mahasiswa tersebut terdiri dari Pendidikan Matematika sebanyak 27 mahasiswa, Pendidikan Fisika sebanyak 23 mahasiswa, Pendidikan Kimia sebanyak 10 mahasiswa, Pendidikan Biologi sebanyak 8 mahasiswa, Pendidikan Bahasa Indonesia sebanyak 20 mahasiswa, serta Pendidikan Bahasa Inggris sebanyak 12 mahasiswa. Analisis data yang digunakan dalam penelitian ini ada dua yaitu analisis data menggunakan pemodelan rasch menggunakan output 
tables 12. Item Map dan juga analisis angket dengan metode deskriptif menggunakan rumus persentase deskriptif.

$$
D p=\frac{n}{N} \times 100 \%
$$

(Ali M. , 2013)

Keterangan:

Dp : Skor yang diharapkan

$\mathrm{N} \quad$ : Jumlah skor maksimum

n : Jumlah skor yang diperoleh

\section{HASIL DAN PEMBAHASAN}

Hasil pengisian angket pada tiap-tiap pernyataan didapatkan hasil sebagai berikut. Pernyataan pertama yang diberikan diangket adalah "saya tertarik untuk membaca materi yang diberikan oleh dosen lewat pembelajaran online".

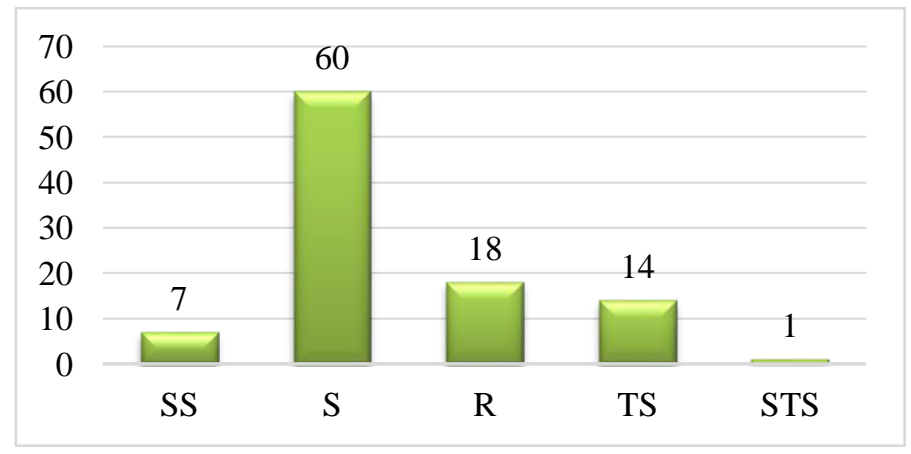

Gambar 1. Pernyataan Pertama

Hasil yang didapatkan adalah kebanyakan mahasiswa FKIP Universitas Papua setuju dengan pernyataan pertama ini, diartikan bahwa mahasiswa FKIP Universitas Papua tertarik untuk membaca materi yang diberikan oleh dosen selama pembelajaran online berlangsung. Hasil ini sesuai dengan penelitian yang telah dilakukan oleh Rizki Nurhaman yang mendapatkan hasil bahwa peseeta pembelajaran memiliki ketertarikan untuk membaca materi pembelajaran yang diberikan (Friantini \& Winata, 2019).

Pernyataan kedua adalah "saya menyukai pembelajaran yang dilakukan menggunakan pembelajaran online" 


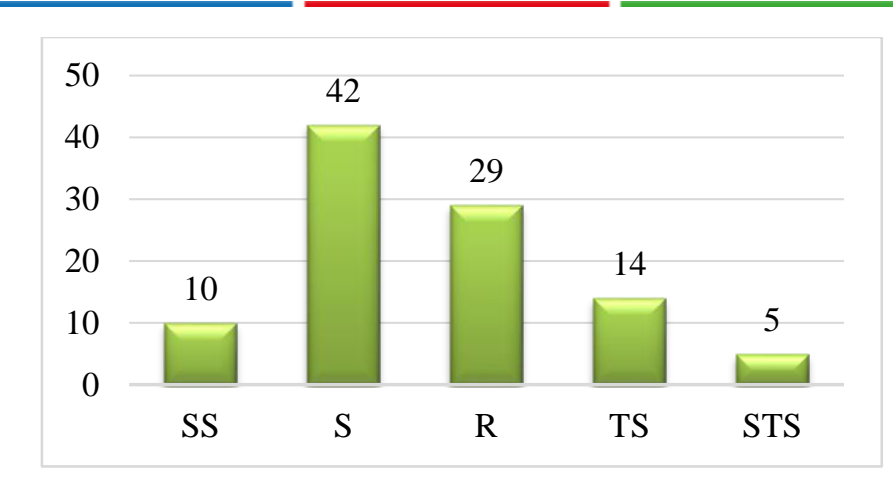

Gambar 2. Pernyataan Kedua

Hasil menyatakan bahwa kebanyakan mahasiswa FKIP Universitas Papua setuju dengan pernyaatan kedua ini. Artinya bahwa mahasiswa FKIP Universitas Papua menyukai pembelajaran yang dilakukan menggunakan pembelajaran online. Pernyataan ini sesuai dengan hasil penelitian yang didapatkan oleh Arpin Chronika yaitu minat belajar dapat dihasilkan salah satunya jika pembelajaran dilakukan menggunakan aplikasi atau sesuatu yang inovatif (Manalu et al., 2019).

Pernyataan ketiga adalah "saya menjadi orang terakhir yang selesai mengerjakan soalsoal yang diberikan oleh dosen selama pembelajaran online".

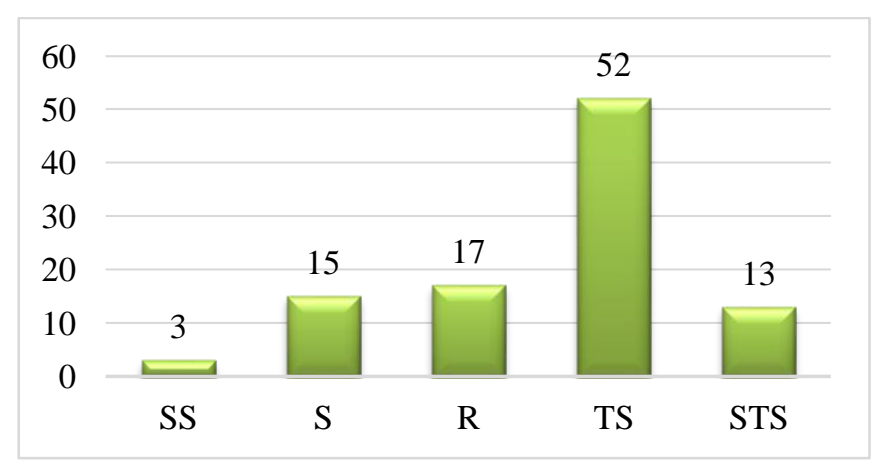

Gambar 3. Pernyataan Ketiga

Hasil ini memberikan informasi bahwa mahasiswa FKIP Universitas Papua mayoritas tidak setuju dengan pernyataan ketiga ini. Hal ini terlihat dari jumlah mahasiswa yang memilih tidak setuju yaitu sebanyak 52 orang. Artinya adalah mahasiswa FKIP Universitas Papua yang mengisi angket ini kebanyakan bukan menjadi orang terakhir yang selesai mengerjakan soal-soal yang diberikan oleh dosen selama pembelajaran online.

Pernyataan keempat adalah "saya tidak senang dengan pembelajaran yang dilakukan secara online". 


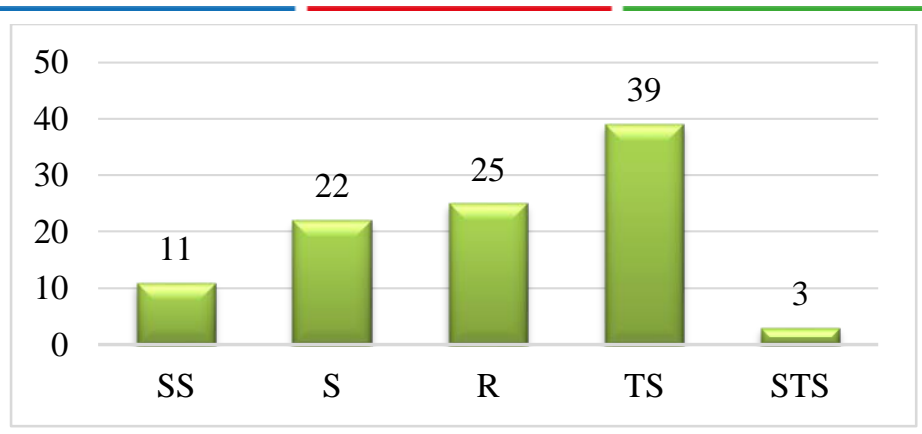

Gambar 4. Pernyataan Keempat

Hasil yang didapatkan adalah mahasiswa FKIP malah merasa senang dengan pembelajaran yang dilakukan secara online. Hasil ini sejalan dengan penelitian oleh Arpin Chronika yaitu salah satu penghasil minat belajar adalah jika pembelajaran dilakukan menggunakan aplikasi atau sesuatu yang baru (Manalu et al., 2019).

Pernyataan kelima adalah "saya memperhatikan semua bahan yang diberikan oleh dosen dalam pembelajaran online yang dilaksanakan".

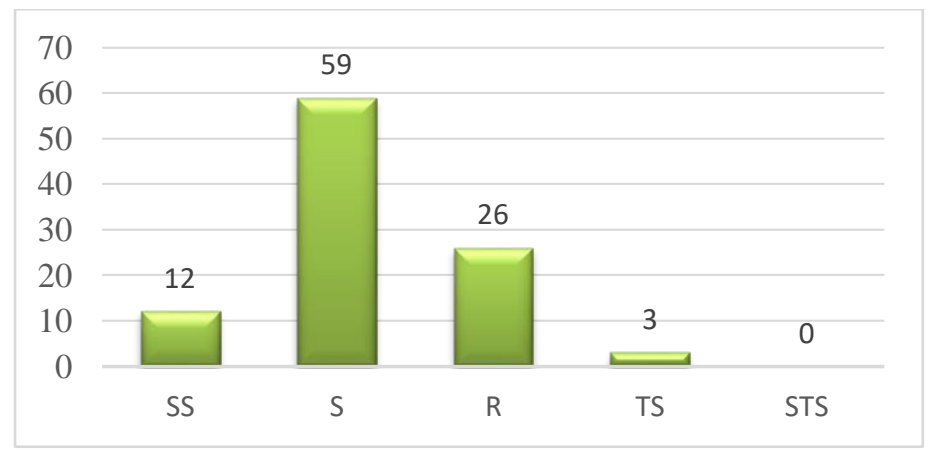

Gambar 5. Pernyataan Kelima

Hasil yang didapat menunjukan bahwa kebanyakan mahasiswa FKIP Universitas Papua memilih setuju untuk menjawab pernyataan kelima ini. Artinya mahasiswa FKIP Universitas Papua memperhatikan semua bahan pembelajaran yang diberikan oleh dosen dalam pembelajaran online.

Pernyataan keenam adalah "saya lebih memahami materi yang diberikan oleh dosen selama pembelajaran online". 




Gambar 6. Pernyataan Keenam

Hasil yang didapatkan adalah mahasiswa masih ragu-ragu dengan pernyataan ini, karena mahasiswa tersebut bingung antara paham atau tidak dengan materi yang diberikan oleh dosen. Sedangkan untuk yang memilih tidak setuju disebabkan oleh lebih seringnya dosen hanya memberikan materi pembelajaran tanpa adanya tindak lanjut

Pernyataan ketujuh adalah "saya malas mengikuti pembelajaran yang dilakukan secara online".

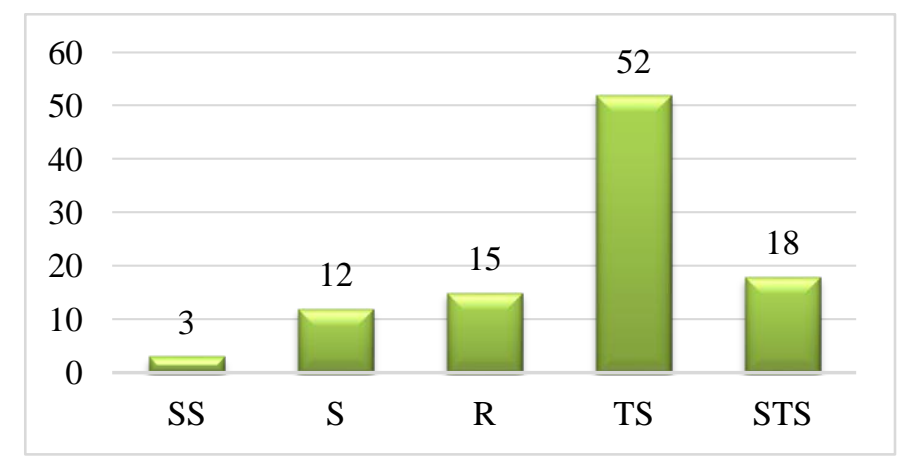

Gambar 7. Pernyataan Ketujuh

Hasil menunjukkan bahwa lebih dari setengah mahasiswa yang mengisi angket tidak setuju dengan pernyataan ketujuh, artinya bahwa mahasiswa FKIP Universitas Papua tidak malas dalam mengikuti pembelajaran yang dilakukan secara online.

Pernyataan kedelapan adalah "saya malas menyelesaikan soal-soal yang diberikan selama pembelajaran online". 




Gambar 8. Pernyataan Kedelapan

Hasil yang didapatkan adalah mahasiswa FKIP Universitas Papua tidak malas (rajin) untuk mengerjakan soal-soal yang diberikan oleh dosen selama pembelajaran online hampir sama dengan hasil yang didapatkan oleh Arpin Chronika yaitu peserta selalu mengerjakan soal-soal yang diberikan selama pembelajaran (Manalu et al, 2019).

Pernyataan kesembilan adalah "saya dapat menyelesaikan soal-soal yang diberikan karena memperhatikan penjelasan dosen selama pembelajaran online berlangsung".

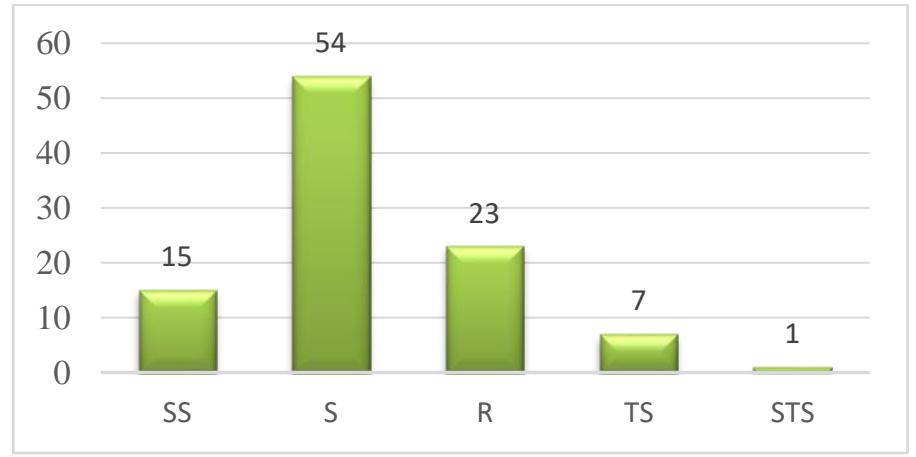

Gambar 9. Pernyataan Kesembilan

Hasilnya adalah mahasiswa FKIP Universitas Papua dapat menyelesaikan soal-soal yang diberikan oleh dosen selama pembelajaran online. Penyebab mahasiswa dapat menyelesaikan soal-soal yang diberikan adalah karena mahasiswa memperhatikan penjelasan yang diberikan oleh dosen selama pembelajaran online berlangsung.

Pernyataan kesepuluh adalah "saya selalu standby untuk mengikuti pembelajaran yang dilakukan secara online”. 


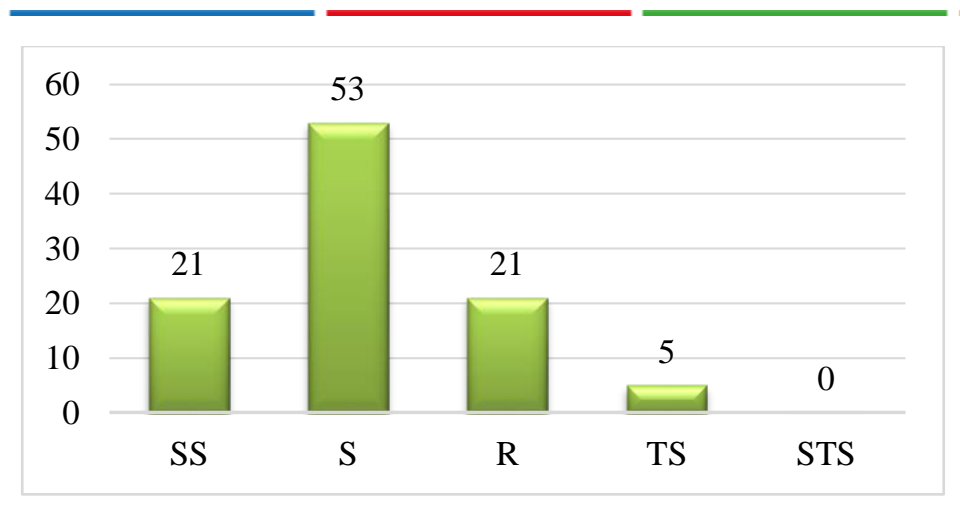

Gambar 10. Pernyataan Kesepuluh

Hal ini menyatakan bahwa mahasiswa FKIP Universitas Papua selalu siap terlebih dahulu dan menunggu untuk mengikuti pembelajaran yang dilakukan secara online. Menurut Susanto (2013) minat belajar tergantung pada kesiapan belajar seperti mempersiapkan diri sebelum pembelajaran dimulai.

Pernyataan kesebelas adalah "saya senang jika menjadi orang pertama yang menyelesaikan soal-soal saat pembelajaran online dilaksanakan".

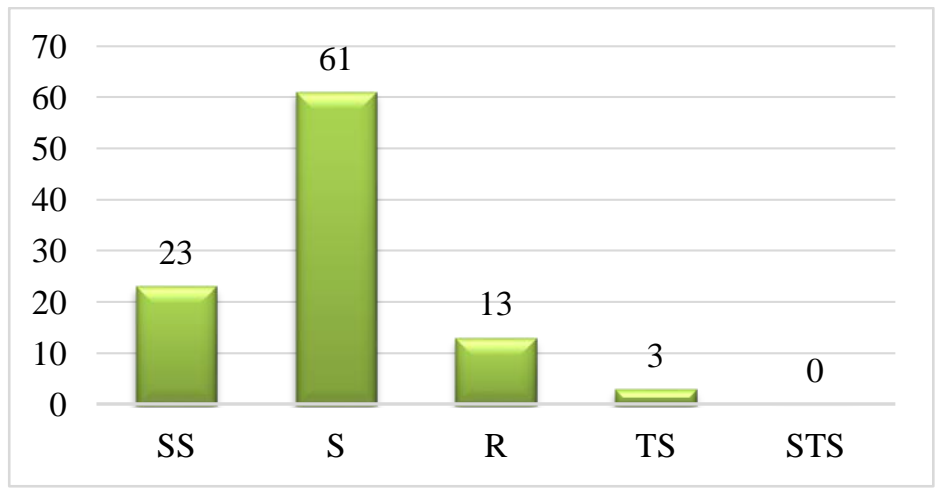

Gambar 11. Pernyataan Kesebelas

Didapati hasil bahwa mahasiswa FKIP Universitas Papua akan merasa senang jika mahasiswa tersebut menjadi orang pertama yang menyelesaikan soal-soal yang diberikan pada saat pembelajaran online. Pernyataan ini hampir sama maksudnya dengan hasil penelitian oleh Rizki yaitu minat belajar muncul dengan adanya kemauan dari dalam diri untuk aktif selama pembelajaran (Friantini \& Winata, 2019).

Pernyataan kedua belas adalah "saya tidak dapat memahami materi yang diberikan oleh dosen selama pembelajaran online”. 


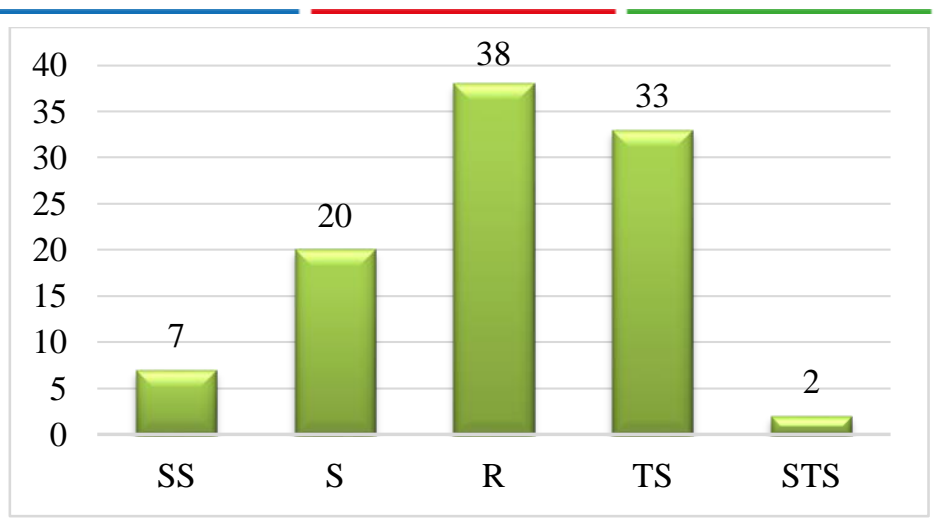

Gambar 12. Pernyataan Kedua Belas

Pada pernyataan kedua belas ini dapat dilihat bahwa mahasiswa FKIP Universitas Papua merasa ragu-ragu dan juga tidak setuju. Untuk mahasiswa yang memilih jawaban ragu-ragu disebabkan oleh rasa kebingungan apakah mahasiswa tersebut memahami atau tidak materi yang diberikan. Alasannya adalah karena kadang mahasiswa tersebut mengerti pada pembahasan pertama tetapi pada pembahasan selanjutnya mahasiswa tersebut sudah tidak paham. Sedangkan untuk pilihan jawaban tidak setuju menyatakan bahwa mahasiswa dapat memahami materi yang diberikan oleh dosen selama pembelajaran online.

Pernyataan ketiga belas adalah "saya tidak dapat menyelesaikan tugas yang diberikan karena tidak memperhatikan pembelajaran yang dilakukan secara online”.

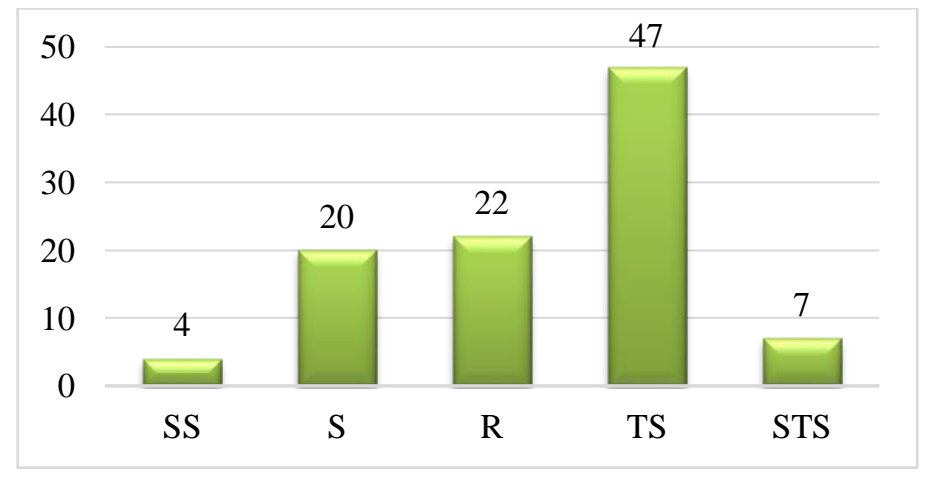

Gambar 13. Pernyataan Ketiga Belas

Hasilnya adalah mahasiswa FKIP Universitas Papua merasa dapat menyelesaikan tugas yang diberikan karena memperhatikan pembelajaran yang berlangsung. Penelitian dari Olenggius juga mendapatkan hasil bahwa peserta yang memperhatikan guru dapat menyelesaikan soal-soal yang diberikan (Dores et al, 2019).

Pernyataan keempat belas adalah "saya berusaha menyelesaikan soal-soal yang diberikan oleh dosen selama pembelajaran online". 


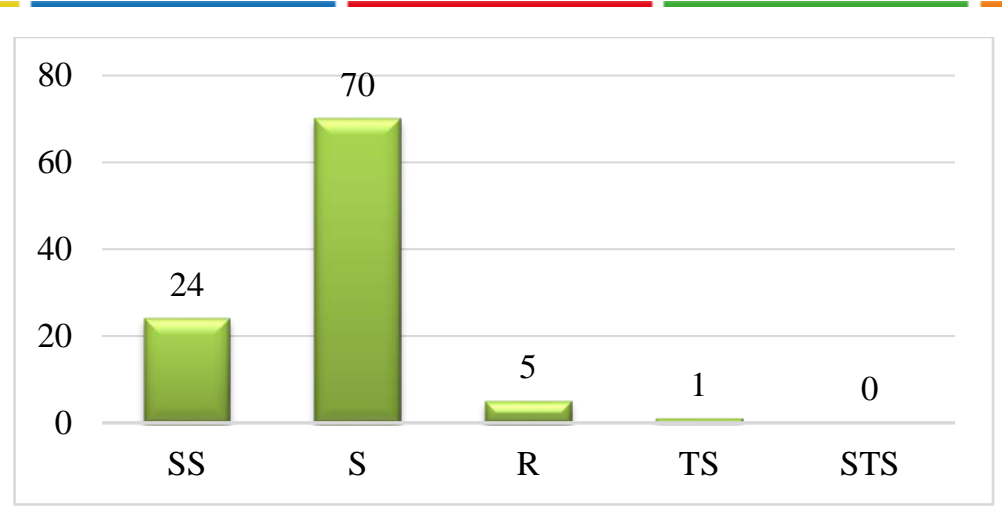

Gambar 14. Pernyataan Keempat Belas

Hasil ini didapati karena mahasiswa FKIP Universitas Papua selalu berusaha untuk menyelesaikan soal-soal yang diberikan oleh dosen selama pembelajaran online. Hasil yang hapir sama juga didapatkan oleh Arpin Chronika yaitu peserta selalu mengerjakan soal-soal yang diberikan selama pembelajaran (Manalu et al, 2019).

Pernyataan kelima belas adalah "saya malas mengikuti pembelajaran online yang dilaksanakan".

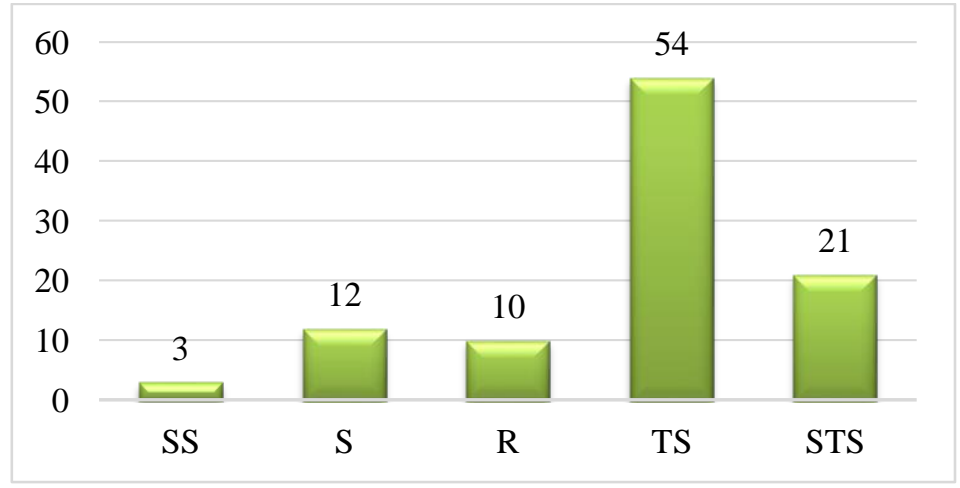

Gambar 15. Pernyataan Kelima Belas

Dari hasil diatas dapat dilihat bahwa jawaban terbanyak yang diberikan oleh mahasiswa FKIP Universitas Papua adalah tidak setuju dan sangat tidak setuju dengan jumlah keseluruhan 75 mahasiswa. Artinya bahwa mahasiswa FKIP Universitas Papua tidak malas untuk mengikuti pembelajaran online yang dilaksanakan. Penelitian dari Olenggius juga mendapatkan hasil bahwa minat belajar peserta didik dilihat dari kemauan peserta untuk mengikuti pembelajaran yang masuk dalam kategori tinggi (Dores et al, 2019).

Minat belajar mahasiswa juga dianalisis menggunakan pemodelan Rasch menggunakan Item Maps. Kegunaan dari analisis menggunakan item map adalah untuk mendeskripsikan tiap-tiap pernyataan. Output table yang digunakan untuk mengetahui posisi person dan item adalah output tables 12. Item Map pada Gambar 16. Hasil item map pada sisi bagian kiri 
menandakan tingkat minat mahasiswa FKIP Universitas Papua, semakin tinggi nilai logitnya maka semakin besar minat belajarnya. Minat belajar mahasiswa dengan kode 040 dan masuk dalam salah satu mahasiswa yang memiliki minat belajar tertinggi, sedangkan mahasiswa dengan kode 033 merupakan salah satu mahasiswa yang memiliki minat belajar terendah. Sesuai dengan persentase deskriptif yang telah didapatkan maka mahasiswa dengan kode 040 masuk dalam kategori minat belajar sangat tinggi dan mahasiswa dengan kode 033 masuk dalam kategori minat belajar sedang.

Pembacaan item map untuk sisi bagian kanan adalah semakin tinggi nilai logitnya maka semakin sulit untuk mahasiswa menyutujui pernyataan atau item tersebut. Hasil item map didapatkan hasil bahwa pernyataan P6 yaitu "saya lebih memahami materi yang diberikan oleh dosen selama pembelajaran online" memiliki nilai logit paling tinggi yang menyatakan bahwa mahasiswa dengan mudah menjawab "tidak setuju" dengan pernyataan yang diberikan. Hal ini sesuai dengan hasil yang didapatkan lewat angket minat belajar mahasiswa, dimana kebanyakan mahasiswa menjawab tidak setuju dengan pernyataan ini. Pernyataan dengan kode P14 yaitu "saya berusaha menyelesaikan soal-soal yang diberikan oleh dosen selama pembelajaran online" memiliki nilai logit terkecil yang menyatakan bahwa mahasiswa dengan mudah menjawab "setuju" dengan pernyataan yang diberikan. Hasil ini sesuai dengan hasil angket minat belajar mahasiswa yang didapatkan, yaitu hampir keseluruhan mahasiswa menjawab setuju dengan pernyataan ini. Selanjutnya akan dihitung persentase minat belajar. Perhitungan persentase minat belajar menggunakan persamaan persentase deskriptif pada Persamaan (1). Ringkasan hasil dari angket minat belajar dalam bentuk persentase deskriptif pada tiap-tiap indikator dapat dilihat pada Tabel 1. 
Gambar 16. Person dan Item Map

Tabel 1. Persentase Deskriptif pada Tiap Indikator Minat

\begin{tabular}{|c|c|c|c|}
\hline \multirow{2}{*}{$\begin{array}{c}\text { Predikat Persentase } \\
\text { Deskriptif }\end{array}$} & \multicolumn{3}{|c|}{ Persentase (\%) } \\
\cline { 2 - 4 } & Rasa Tertarik & Rasa Senang & Rasa Perhatian \\
\hline Sangat tinggi & 23 & 23 & 8 \\
\hline Tinggi & 64 & 56 & 61 \\
\hline Sedang & 13 & 19 & 29 \\
\hline Rendah & 1 & 2 & 2 \\
\hline Sangat rendah & - & - & - \\
\hline
\end{tabular}

Puplished at https://ojs.stkippgri-lubuklinggau.ac.id/index.php/SJPIF 


\section{KESIMPULAN}

Berdasarkan hasil temuan dan juga pembahasan, dapat disimpulkan bahwa minat belajar mahasiswa FKIP Universitas Papua pada pembelajaran online masuk dalam tiga kategori. Pada indikator rasa senang didapatkan hasil minat belajar belajar sangat tinggi sebanyak $23 \%$, kategori minat belajar tinggi sebanyak 56\%, dan kategori minat belajar sedang sebanyak 19\%, dan kategori rendah sebanyak $2 \%$. Pada indikator rasa tertarik didapatkan hasil minat belajar belajar sangat tinggi sebanyak 22\%, kategori minat belajar tinggi sebanyak 64\%, kategori minat belajar sedang sebanyak 13\%, dan kategori rendah sebanyak 1\%. Pada indikator rasa perhatian didapatkan hasil minat belajar belajar sangat tinggi sebanyak $8 \%$, kategori minat belajar tinggi sebanyak 61\%, kategori minat belajar sedang sebanyak 29\%, dan kategori rendah sebanyak 2\%. Mahasiswa dominan memiliki minat pada rasa tertarik untuk menyelesaikan soal-soal yang diberikan oleh dosen selama pembelajaran online. Hal ini didukung oleh hasil persentase deskriptif pada tiap indikator dan hasil analisis menggunakan pemodelan Rasch. Beberapa saran yang dapat diberikan peneliti berdasarkan hasil penelitian mengenai analisis minat belajar mahasiswa FKIP Universitas Papua pada pembelajaran online yaitu mengoptimalkan transfer ilmu pada mahasiswa agar lebih dapat memahami materi dalam pembelajaran online, perlu lebih kreatif lagi dalam menyajikan materi agar lebih menarik minat mahasiswa dalam megikuti pembelajaran, dan semoga penelitian ini dapat digunakan lagi untuk menjadi sumber referensi dan juga pertimbangan untuk penelitian serupa yang akan dilakukan dikemudian hari.

\section{DAFTAR PUSTAKA}

Ariani, T., \& Yolanda, Y. (2019). Effectiveness of Physics Teaching Material Based on Contextual Static Fluid Material. Kasuari: Physics Education Journal (KPEJ), 2(2), $70-81$.

Arikunto, S. (2003). Prosedur Penelitian Suatu Pendekatan Praktek (Edisi Revisi). Jakarta: PT Rineka Cipta.

Aristo. (2003). Media Pembelajaran. Jakarta: Departemen Pendidikan Nasional.

Charli, L., Ariani, T., \& Asmara, L. (2019). Hubungan Minat Belajar terhadap Prestasi Belajar Fisika. SPEJ (Science and Physic Education Journal), 2(2), 52-60.

Dores, O.J., Huda F.A., Riana R. (2019). Analisis Minat Belajar Matematika Siswa Kelas IV Sekolah Dasar Negeri 4 Sirang Setambang Tahun Pelajaran 2018/2019. J-PIMat, 1(1), $38-48$. 
Friantini R.N., Winata R. (2019). Analisis Minat Belajar Pada Pembelajaran Matematika. Jurnal Pendidikan Matematika Indonesia, 4(1), 6-11.

Khasanah, D. R. A., Pramudibyanto, H., \& Widuroyekti, B. (2020). Pendidikan Dalam Masa Pandemi Covid-19. Jurnal Sinestesia, 10(1), 41-48.

Lovisia, E. (2019). Penerapan Model Pembelajaran Kooperatif Tipe Studentteams achievement division (STAD) pada pembelajaran fisika siswa kelas X SMA Negeri 7 Lubuklinggau. Silampari Jurnal Pendidikan Ilmu Fisika, 1(1), 1-12.

Manalu, A.C.S., Jumiati, Y., \& Setiawan W. (2019). Analisis Minat Belajar Matematika Siswa SMP Kelas VIII Pada Materi Persamaan Garis Lurus Berbantu Aplikasi Geogebra. Journal on Education, 2(1), 63-69.

Megawati. (2014). Pengantar Teknologi Informasi Internet. Jakarta: PT Media Damai.

Norva. (2015). Media dan Perubahan Sosial. Jakarta: Cetakan Putra Utama.

Oktarika, D. (2015). Pengaruh Pembelajaran Menggunakan Media E-Learning Terhadap Minat Belajar Mahasiswa Pada Mata Kuliah E-Learning Di Program Studi P.TIK. Jurnal Pendidikan Informatika Dan Sains, 4(1), 15-26.

Prasojo, L., \& Riyanto. (2011). Teknologi Informasi Pendidikan. Yogyakarta: Gava Media.

Sadirman. (2011) Interaksi dan Motivasi Belajar Mengajar. Jakarta: Rajawali Press.

Slameto. (2010). Belajar dan Faktor-Faktor yang Mempengaruhinya. Jakarta: PT Rineka Citra.

Sugiyono. (2013). Metode Penelitian Pendidikan (Cetakan ke-16). Bandung: Alfabeta.

Sukmadinata. (2009). Landasan Proses Pendidikan. Bandung: PT Remaja Rosdakarya. 